\title{
Pelatihan Pembuatan Face Shields Bagi Masyarakat di Kecamatan Sukaraja Kabupaten Seluma
}

\section{Nola Windirah ${ }^{1}$, M. Mustopa Romdhon ${ }^{2}$, Gustria Ernis ${ }^{3}$}

${ }^{1,2}$ Program Studi Agribisnis, Fakultas Pertanian Universitas Bengkulu

${ }^{3}$ Program Studi D3 Lab Sains, Fakultas MIPA Universitas Bengkulu

E-mail: nolawindirah@unib.ac.id

\section{Article History:}

Received: Juli

Revised: September

Accepted: November

Available online:

Desember

Kata Kunci: face shield, pelatihan, tenaga kesehatan

\begin{abstract}
Abstrak:
Tenaga kesehatan wajib menggunakan standar keselamatan yaitu penggunaan Alat Pelindung Diri (APD) dalam bentuk face shield untuk mencegah penularan dari dan ke petugas kesehatan dan pasien membutuhkan alat pelindung diri. Keteersediaannya yang terbatas mendorong masyarakat untuk berkontribusi aktif membuat APD berupa face shields. Pelatihan Pembuatan face shields menggunakan metode demonstrasi dan metode pembuatan terbimbing. Hasil pengabdian dalam bentuk pelatihan menunjukkan bahwa pelatihan ini telah berhasil melatih anggota masyarakat sebagai perintis pembuatan face shields. Kemampuan dan keterampilan para perintis face shields sangat baik ditunjukkan oleh kemampuan membuat 30 unit face shields yang telah dikontribusikan kepada petugas kesehatan di Puskesmas Babatang Kecamatan Sukaraja Kabupaten Seluma.
\end{abstract}




\section{Pendahuluan}

Wuhan menjadi Negara pertama ditemukannya virus jenis baru pada tahun 2020, Coronavirus (SARS-Cov-2) menjadi nama pengenal virus tersebut dan penyakitnya disebut dengan Coronavirus disease 2019 (Covid19) (Yuliana, 2020). Manusia yang terinfeksi Covid-19 sebanyak 92 orang per tanggal 9 Juni 2020 di Provinsi Bengkulu. Virus yang bermula di Wuhan sejak 31 Desember 2019 mampu menginfeksi saluran pernapasan. Orang terkonfirmasi positif covid-19 sebanyak 2 orang di Kecamatan Sukaraja Kabupaten Seluma, sehingga daerah ini telah masuk Zona merah sejak april 2020. Informasi ini membuat peluang penularan Covid-19 semakin besar, sehingga diperlukan langkah-langkah antisipasi, sementara mode transmisi dan penyebaran melalui kontaminasi lingkungan belum diketahui (Sean, 2020).

Pusat Pelayanan Kesehatan Pertama berperan sangat penting sebagai garda terdepan dalam mengatasi pandemik Covid-19. Fakta menunjukkan tenaga kesehatan belum menggunakan standar keselamatan yaitu penggunaan Alat Pelindung Diri (APD) dalam bentuk face shield untuk menjalankan tugas mereka. Pencegahan penularan dari dan ke petugas kesehatan dan pasien membutuhkan alat pelindung diri (Livingston, 2020)

Alat Pelindung Diri (APD) adalah perlengkapan yang wajib digunakan untuk melindungi tenaga kerja khususnya tenaga kesehatan dari bahaya yang bisa menyebabkan cidera atau penyakit serius seperti Pandemi Covid_19 . Perencevich (2020); Sean (2020) menyatakan ada dua cara sederhana mencegah droplet melalui pernafasan yaitu menggunakan face masks dan face shields. Bentuk face shields bervariasi, sebagian besar berbahan plastic bening (jernih) sebagai pelindung wajah. Secara Umum APD dibedakan sebagai berikut : 1) Alat Pelindung Kepala, 2) Alat Pelindung Mata dan Muka, 3) Alat Pelindung Telinga, 4) Alat Pelindung Saluran Pernapasan, 5) Alat Pelindung Tangan, 6) Alat Pelindung Kaki, 7) Pakaian Pelindung, 8) Sabuk dan Tali Keselamatan, dan 9) Pelampung ( Livingstone, 2020). 
Alat Pelindung Diri (APD) yang menjadi materi pelatihan termasuk jenis Alat Pelindung mata dan muka berupa face shields atau full face masker. Fungsi face shields melindungi mata dan muka dari paparan bahan kimia berbahaya, gas, partikel yang melayang di udara atau air, percikan benda kecil, panas atau uap (droplet) (Perencevich, 2020). Fungsinya lainnya juga menutup wajah dan mata dari gangguan kesehatan atau cidera akibat paparan radiasi, pancaran cahaya dan benturan atau pukulan benda keras atau tajam (Adrian, 2019). Optimalisasi perlindungan, penutup harus melebar sampai ke bawah dagu melebar sampai menutup telinga dan tidak dan celah terbuka. Hasil riset menunjukkan bahwa efektifitas penggunaan face shields bisa melindungi penggunanya dari paparan virus sampai diatas 90\%,dengan rentang efikasi $68 \%$ sampai dengan $96 \%$ saat digunakan dalam jarak setengah meter dari orang yang batuk (Lindsley, 2014). Artinya masih ada peluang penularan terjadi melalui bagian tubuh tenaga kesehatan yang terpapar (Feldman, 2020).

Puskesmas Babatan salah satu pusat pemantauan kesehatan masyarakat di Kecamatan Sukaraja, sehingga penggunaan face shields bagi tenaga kesehatan sangat penting. Ketersediaan face shields terbatas di Puskesmas menyebabkan tenaga kesehatan harus menggunakan face shields bergantian untuk mengkonfirmasi warga dengan gejala Covid-19. Kondisi ini ditakutkan akan semakin memperbesar peluang penularan di Kecamatan Sukaraja. Oleh karena itu, kegiatan ini bertujuan untuk memberikan keterampilan baru yakni produksi face shields pada warga sekitar Puskesmas Babatan. Produk face shields hasil pelatihan diberikan kepada tenaga kesehatan di Puskesmas Babatan Kecamatan Sukaraja.

\section{Metode} berikut :

Pengabdian dilaksanakan dengan menggunakan metode sebagai 1. Metode Penentuan Lokasi Pengabdian

Pengabdian ini dilaksanakan di Desa Jenggalu Kecamatan Sukaraja Kabupaten Seluma pada bulan Mei tahun 2020. Desa ini dipilih karena berada dekat dengan Puskesmas Babatan. 


\section{Metode Pembuatan Terbimbing}

Metode pembuatan terbimbing dibagi menjadi menjadi tiga tahap, yaitu : Tahap Persiapan mencakup pengurusan perizinan adminsitrasi dan pembelian alat dan bahan berupa gunting, pisau carter, spidol, pengaris, tali karet, elastis, kertas sticker, pin penjempit, lem perekat serta mika dan sponge. Tahap Pembuatan face shields semua bahan diukur dan dipotong sesuai ukuran yang ditentukan yaitu mika $33 \times 25 \mathrm{~cm}$, sponge $25 \times 3 \times 3 \mathrm{~cm}$, tali $25 \mathrm{~cm}$, stiker $4 \times 30 \mathrm{~cm}$, dan alas sponge $4 \times 33 \mathrm{~cm}$. Tahap Penyerahan face shields kepada puskesmas sasaran yaitu puskesmas Babatan Kecamatan Sukaraja Kabupaten Seluma.

\section{Metode Demonstrasi}

Pelatihan dilakukan di salah satu rumah warga yang diikuti sebanyak 2 orang perintis. Mereka yang telah dilatih diharapkan akan memberikan pelatihan pembuatan face shields kepada warga lainnya. Pelatihan dilaksanakan mulai pukul 10.00 wib hingga 14.00 wib. Instruktur pelatihan merupakan ketua tim pengabdian dengan bantuan satu warga lainnya. Kegiatan pengabdian selanjutnya berupa pembagian APD Face shields sebanyak 30 unit kepada pihak Puskesmas Babatan. Produksi face shields dilakukan oleh peserta pelatihan langsung dengan pengawasan langsung dari tim pengabdian. Pembagian APD Face shields dilakukan pada Selasa $12 \mathrm{Mei}$ 2020 dan langsung diserahkan kepada Kepala Puskesmas Babatan Kecamatan Sukaraja Kabupaten Seluma.

\section{Hasil dan Pembahasan}

Pelaksanaan pelatihan di Desa Jenggalu Kecamatan Sukaraja Kabupaten Seluma dilakukan tanpa adanya acara resmi penyambutan oleh perangkat desa. Hal ini sesuai kesepakatan Tim Pengabdian, Perangkat Desa dan Perintis peserta pelatihan untuk menerapkan protokol kesehatan selama masa pandemi Covid-19. Perizinan perangkat desa dilakukan secara langsung oleh kepala desa sebelum pelaksanaan pengabdian dilaksanakan. Kegiatan pelatihan langsung diserahkan oleh peserta pelatihan dan tim pengabdian. 


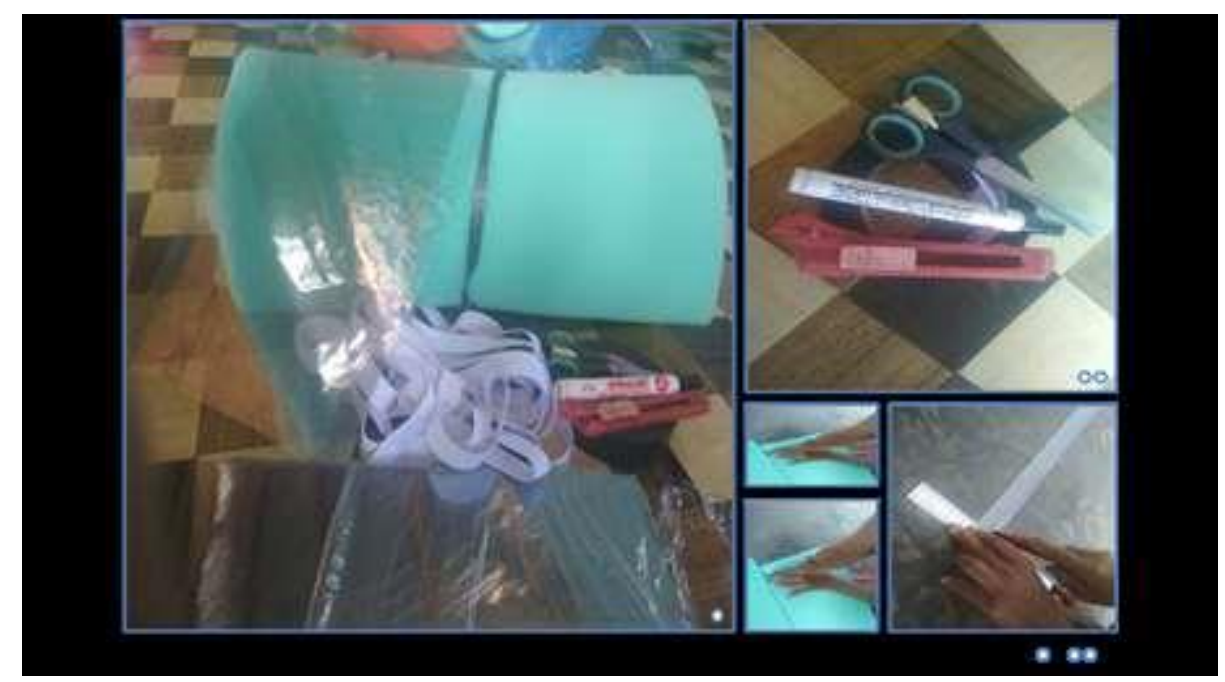

Gambar 1, Bahan dan Alat Pembuatan face shields

Pelatihan pembuatan APD face shields dilakukan di rumah salah satu peserta pelatihan. Jumlah peserta pelatihan dibatasi karena dua pertimbangan yaitu yang pertama, pelatihan ini menerapkan prinsip penyebaran luas keterampilan pembuatan face shields sangat efektif bilamana langsung dilaksanakan oleh anggota masyarakat yang telah terampil. Artinya Keterampilan baru berupa pembuatan APD face shields diharapkan mampu tersalur dengan merata kepada seluruh warga Desa Jenggalu dengan sistem rantai (satu peserta melatih satu warga lainnya dan seterusnya secara berantai). Metode ini juga efektif memotivasi peserta pelatihan untuk terlibat secara aktif semua tahapan (Maurits, 2009). Pertimbangan kedua, adanya penerapan protokol kesehatan antar a lain ada larangan untuk berkumpul selama masa pandemi Covid-19. Hasil riset menunjukkan menjaga jarak antar individu atau menghindari kerumunan dalam jarak setengah meter dari orang yang batuk menjadi salah satu upaya mengurangi tingkat penularan penyakit (Lindsley, 2014)2014). 


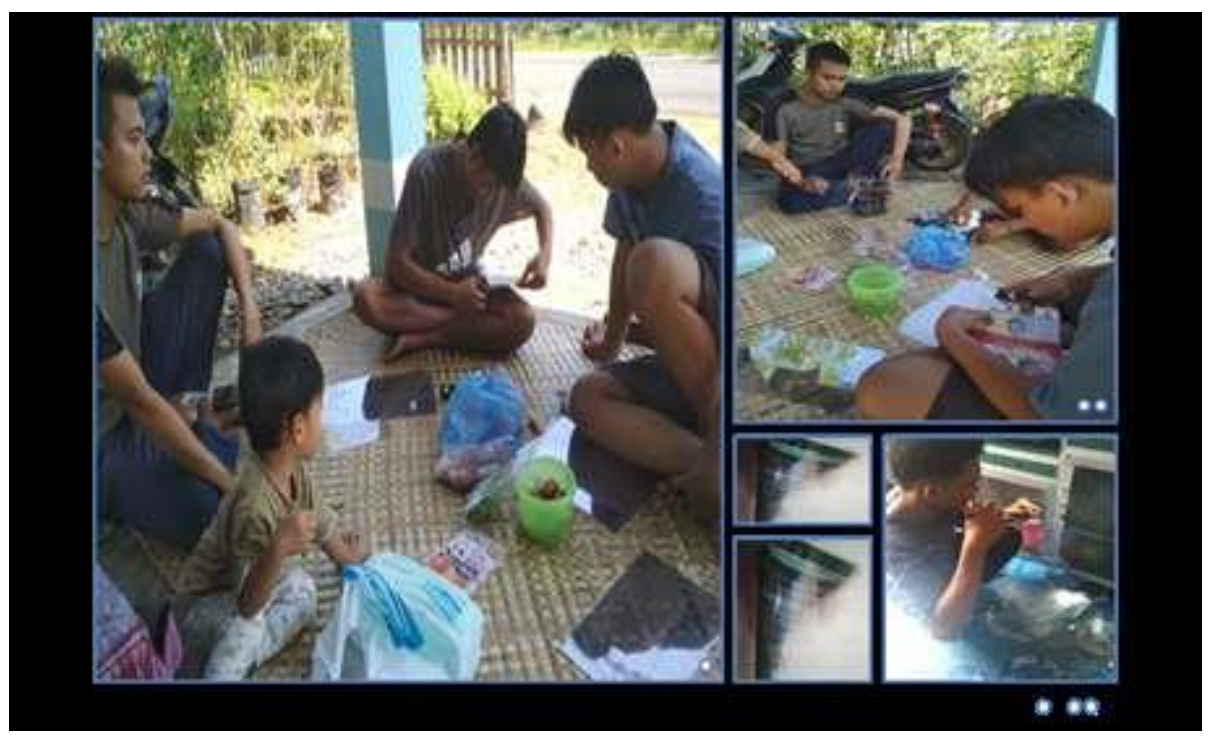

Gambar 2, Proses Pembuatan face shields

Pembuatan face shields dilakukan hingga produksi sebanyak 30 unit untuk pemenuhan kebutuhan tenaga kesehatan Puskesmas Babatan. Jumlah ini menjadi salah satu indikator tingkat keterampilan pembuatan face shields yang dicapai oleh pionir peserta pelatihan. Kegiatan ini dapat memastikan pionir peserta pelatihan memiliki tingkat pemahaman yang tinggi dalam mengaplikasikan keterampilan baru tersebut. Oleh karena itu, apabila ada peningkatan jumlah kebutuhan APD berupa face shields, maka pionir peserta pelatihan sudah mampu untuk produksi secara mandiri. Selain itu, keterampilan baru tersebut diharapkan dapat dijadikan peluang berusaha oleh masyarakat desa untuk menambah pendapatan rumah tangga. Saat ini kebutuhan Alat Pelindung Diri (APD) dalam berbagai bentuk sangat besar (Anonim, 2020), demikian pula kebutuhan face shields sangat besar sehingga membuka peluang pasar. 


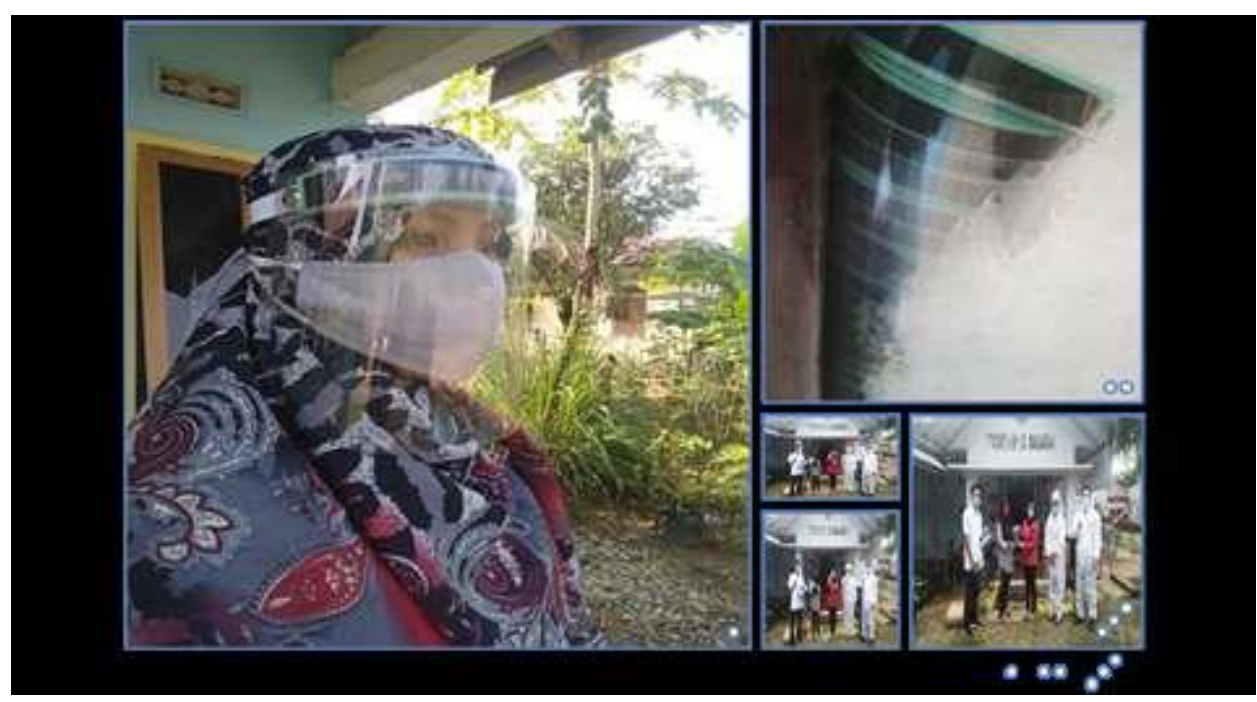

Gambar 3. Produk Akhir: face shields

Pembagian face shields sebanyak 30 unit kepada Puskesmas Babatan dimaksud untuk mengatasi permasalahan berupa kekurangan face shields yang dialami tenaga medis Puskesmas Babatan. Upaya ini merupakan salah satu bentuk partisipasi masyarakat dalam pencegahan penyebaran pandemi Covid19 secara bersama-sama. Partisipasi komunitas ini menjadi salah satu bentuk modal social, menurut Putnam (2000) dan Coleman (2000) adalah jaringan, norma dan kepercayaan yang memfasilitasi kerjasama dan koordinasi. Bentuk modal social ini dipercaya sangat efektif menjadi ujung tombak untuk membangun kesadaran tentang penting nya kebersamaan dalam masa-masa darurat baik darurat sosial, lingkungan terlebih darurat kesehatan yang berdampak luas.

Pendistribusian bantuan face shields kepada para tenaga kesehatan terutama, mereka yang berada di pusat layanan kesehatan pertama seperti puskesmas dengan sejumlah pertimbangan antar lain : pertama, tenaga kesehatan di puskesmas menjadi garda terdepan yang melayani masyarakat yang mengalami masalah kesehatan tidak terkecuali masyarakat yang sakit dengan gejala-gejala mirip gejala covid. Kedua, ketersediaan Alat Pelindung Diri (APD) bagi tenaga medis di Puskesmas Babatang khususnya sangat terbatas, sehingga APD yang ada tidak jarang digunakan secara bergantian 
antar petugas kesehatan.

Kondisi ini dikhawatirkan akan menimbulkan paparan terhadap tenaga kesehatan yang bertugas, padahal jumlah tenaga kesehatan sangat terbatas. Dua pertimbangan ini mampu menjamin fungsi keberadaan tenaga kesehatan di puskesma dalam memberikan edukasi dan layanan kesehatan primer kepada masyarakat dapat terlaksana dengan baik dalam penangaanan Virus Covid19.Kondisi ini dikhawatirkan akan menimbulkan paparan terhadap tenaga kesehatan yang bertugas, padahal jumlah tenaga kesehatan sangat terbatas. Dua pertimbangan ini mampu menjamin fungsi keberadaan tenaga kesehatan di puskesma dalam memberikan edukasi dan layanan kesehatan primer kepada masyarakat dapat terlaksana dengan baik dalam penangaanan Virus Covid-19.

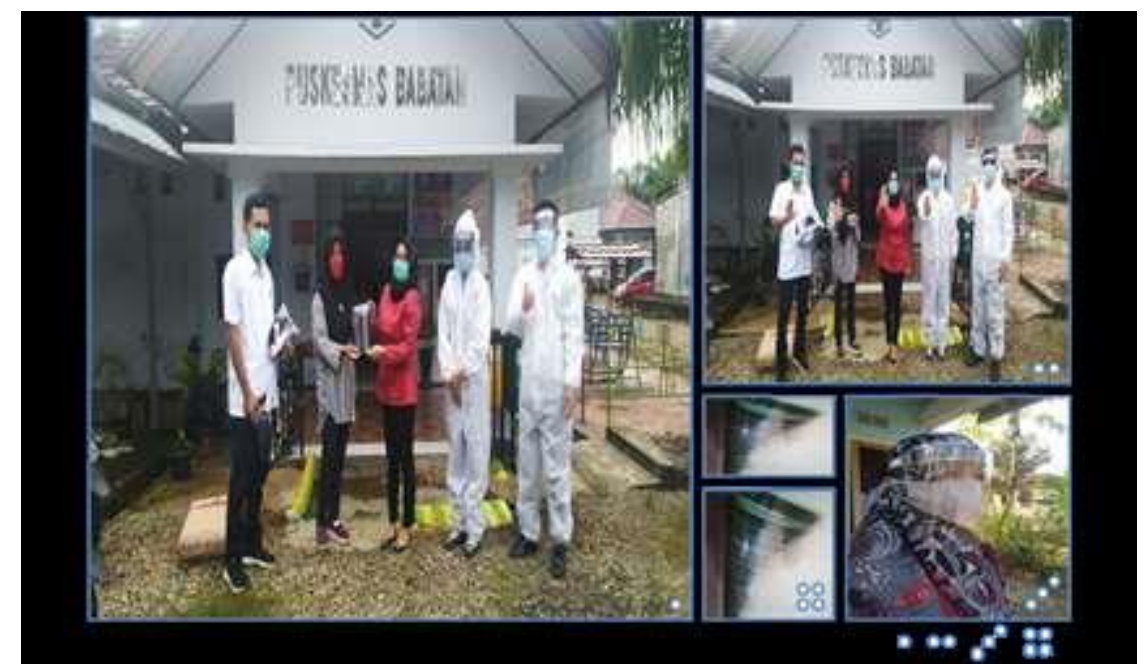

Gambar 4. Penyerahan Bantuan face shields ke Petugas Puskesmas Babatan Kecamatan Sukaraja Kabupaten Seluma

\section{Kesimpulan}

Kesimpulan dari hasil pengabdian kepada masyarakat Pelatihan Pembuatan Face shields bagi Masyarakat Di Kecamatan Sukaraja Kabupaten Seluma antara lain : 
1. Pelatihan Pembuatan Alat Pelindung Diri (APD) berupa face shields kepada perintis di masyarakat Desa Jenggalu telah berhasil dilaksanakan oleh tim pengabdian.

2. Kemampuan dan keterampilan para perintis dalam membuat face shields sangat baik. Dua orang perintis yang dilatih telah mampu membuat face shields sebanyak 30 unit.

3. Face shields yang berhasil dibuat telah didistribusikan kepada petugas kesehatan di Puskesmas Babatang Kecamatan Sukaraja Kabupaten Seluma.

Berdasarkan hasil pelatihan ini, maka diberikan saran kepada para pemangku kepentingan dibidang kesehatan masyarakat yaitu :

1. Kegiatan ini perlu dilanjutkan untuk memberikan ilmu, pengetahuan, serta keterampilan berupa teknologi dan inovasi yang sederhana dan tepat guna bagi masyarakat.

2. Keterampilan yang telah diperoleh perintis dapat disebarluaskan kepada anggota masyarakat lain, sehingga keterampilan ini bisa menjadi salah satu sumber untuk meningkatkan ekonomi keluarga yang mengalami dampak efek pandemik Covid-19.

3. Pemerintah Desa Jenggalu melalui Kepala Desa dapat memfasilitasi dan mengkoordinir kebutuhan para warga untuk memperoleh ilmu, pengetahuan dan keterampilan khusus yang diberikan oleh pengabdi dari Universitas Bengkulu.

\section{Pengakuan/Acknowledgements}

Ucapan terimakasih kepada warga Desa Jenggalu Kecamatan Sukaraja Kabupaten Seluma yang bersedia mengikuti pelatihan Face shield, serta terimakasih kepada pihak Puskesmas Babatan yang bersedia menjadi Mitra.

\section{Daftar Referensi}

Adrian, K. 2019. Mengenal Alat Pelindung Diri dan Jenisnya. https:www.alodokter.com

Coleman, J.2000. Social Capital in The Creation of Human Capital . In Knowledge and Social Capital in P.Dasgupta and I.Serageldin (eds) Social Capital. A Multifaceted Perspective. Washingthon : The World 
Bank.

Industri Tekstil Bisa Menjadi Pemain APD dan Masker Dunia Saat Pandemi Usai. 2020. https://katadata.co.id

Lindslesy WG, Noti JD, Blachere FM, Szalajda JV, Beezhold DH. 2012. Efficay of Face shields agints Cough Aerosol droplets from a cough simulator. J Occup Eniron Hyg. 11(8):509-518

Livingston, E., Desai, A., Berkwits, M. 2020. Sourcing Personal Protective Equipment During the Covid-19 Pandemic. JAMA323(19):1911-1911. Doi:10.1001?jama.2020.4770.

Maurits, L.S. 2009. Efektifitas Pelatihan Keselamatan dan Kesehatan Kerja (K3) dalam Penggunaan Alat Pelindung Diri (APD) PT Mega Andalan Kalasan Yogyakarta. Tesis S2 Ilmu Kesehatan Kerja. UGM.Yogyakarta.

Oren Feldman, Michael Meir, Danielle Shavit. 2020. Exposure to a surrogate measure of contamination from simulated patients by emergency department personnel wearing personal protective equipment. JAMA. 323(20):2091-2093. Doi:10.1001?jama.2020.6633.

Perencevich, E.N.,Daniel, J.D., Michael B.E. 2020. Moving Personal Protective Equipment Into The Community. Face shields and Containment of Covid-19. 323(22):2252-2253. JAMA. DOI:10.1001?jama.2020.2467.

Putnam. RD. 2000. Bowling Alone : The Collapse and Revival of American Community. New York:Simon and Schuster.

Sean Wei, XO, Yian Kim Tan, Po Ying Chia. 2020. Air, Surface Environment, and personal protective equipment contamination by severe acute respiratory syndrome coronavirus (SARS-CoV-2) From a Symptomatic Patient. JAMA 323(16):1610-1612. Oi : 10.1001/jama.2020.3227. 